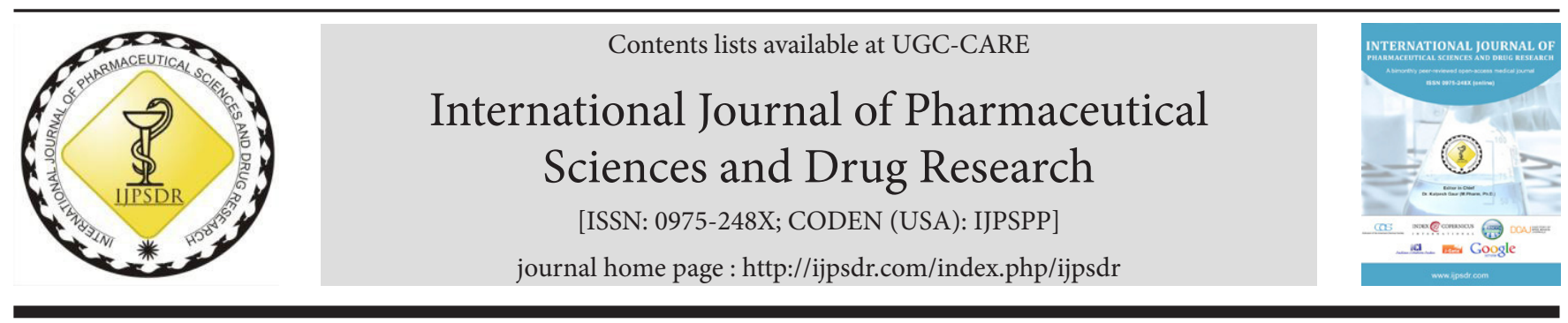

Research Article

\title{
Synthesis and Antidiabetic Evaluation of some Novel Nitrogen- containing Small Heterocyclic Derivatives
}

\author{
Gagandeep Kaur*, Isha Rani \\ Maharishi Markandeshwar University, Sadopur, Near Omaxe Flats, Ambala Chandigarh Expy, Ambala-134007, Punjab, India
}

\begin{tabular}{l} 
A R T I C L E I N F O \\
\hline Article history: \\
Received: 22 April, 2020 \\
Revised: 05 August, 2020 \\
Accepted: 21 August, 2020 \\
Published: 30 September, 2020 \\
Keywords: \\
Anti-diabetic evaluation, \\
Characterization, \\
Docking, Synthesis. \\
D0I: \\
10.25004/IJPSDR.2020.120507
\end{tabular}

\section{INTRODUCTION}

With the aid of its everyday biochemical reactions, the human body regularly builds reactive compounds, against that there is an antioxidant protection network. ${ }^{[1]}$ Despite, when there may be an inequality, either by elevated construction of those reactive compounds or from a decrease within the protection system, an environment leads to build up oxidative stress. ${ }^{[2]}$ Under these conditions, reactive species produce additive damage to biomolecules, including lipids, proteins, and DNA, related to numerous chronic diseases, such as, diabetes mellitus. ${ }^{[3]}$

Diabetes mellitus refers to an accumulation of chronic disorders occurring with divergent multiple etiologies. It consists of excessive levels of blood glucose (hyperglycemia) due to the malfunctioning in insulin action and/or insulin secretion, induce impaired metabolism of carbohydrates, proteins, and lipids in the body. ${ }^{[4]}$
Diabetes is correlated with macrovascular and microvascular complexity, which is the main cause of death and morbidity in diabetic persons. ${ }^{[5]}$ Diabetes can be controlled through medicines, physical activity, and weight loss programs that are both too costly or have undesirable aftereffects or contraindications. ${ }^{[6]}$ Consequently, the search for more secure and more effective anti-diabetic agents has endured being a field of research of concern. The World Health Organization (WHO) has encouraged and recommended using other ways of therapy, mainly in those areas where the approach to the conventional therapy of hyperglycemia is not satisfactory. ${ }^{[7]}$

Thiazolidinediones are also a member of fivemembered heterocyclic compounds with sulfur, oxygen, and nitrogen atom in their structure and have a wide range of pharmacological activities. ${ }^{[8]}$ Plasma glucose and insulin levels are reduced by thiazolidinediones (TZDs), and limited lipid metabolism abnormalities also get

\footnotetext{
${ }^{*}$ Corresponding Author: Gagandeep Kaur

Address: Maharishi Markandeshwar University, Sadopur, Near Omaxe Flats, Ambala Chandigarh Expy, Ambala-134007, Punjab, India

Email $₫$ : gagan17986@gmail.com

Relevant conflicts of interest/financial disclosures: The authors declare that the research was conducted in the absence of any commercial or financial relationships that could be construed as a potential conflict of interest.

Copyright (C) 2020 Gagandeep Kaur et al. This is an open access article distributed under the terms of the Creative Commons AttributionNonCommercial-ShareAlike 4.0 International License which allows others to remix, tweak, and build upon the work non-commercially, as long as the author is credited and the new creations are licensed under the identical terms.
} 
improved. Persistent with animal studies, clinical studies have revealed that treatment with thiazolidinediones can lower insulin levels and serum glucose of type 2 diabetic patients with TZDs, besides increasing peripheral glucose uptake and decreasing triglyceride levels. Moreover, several heterocyclic moieties, such as, benzoxazinone, benzoxazole, benzofuran, pyrimidinone, etc., have been clubbed with thiazolidine-2,4-dione and were found to show a good to a significant profile of activities. ${ }^{[9]}$ Therefore, a conscious effort is made in the chemistry part of the present work to cull out selective modifications of the thiadiazole and dione skeletons.

\section{Materials AND METhods}

\section{Chemistry}

The reagents and solvents were used as usual. TLC was executed by utilizing precoated silica plates (Merk, Silica gel $60 \mathrm{~F}_{254}$ ) for analysis. Open glass capillary tubes in the Thiele's tube were used for the determination of the melting point and are not corrected. The infrared (IR) spectra of all intermediates and final derivatives were reported on a FT-IR spectrometer having $\mathrm{KBr}$ pellets with $v_{\max }$ values stated in $\mathrm{cm}^{-1}$. The ${ }^{13} \mathrm{C}$-NMR and ${ }^{1} \mathrm{H}$-NMR spectra of the synthesized derivatives were collected from Bruker Avance II 400 NMR spectrometer in DMSO.

\section{General Method of Synthesis of Thiadiazole Derivatives (1)}

Benzoic acid $(0.048 \mathrm{M})$ and thiosemicarbazide $(0.048 \mathrm{~mol})$ in equimolar quantities were mixed together in phosphorus oxychloride $(16 \mathrm{~mL})$ and refluxed it gently for at least 30 minutes. After that, cooled down the mixture at room temperature, and $90 \mathrm{~mL}$ of water is added to it. The solution is refluxed again for 4 hours, and it is filtered while hot. Basification is done by the addition of an aqueous solution of potassium hydroxide while stirring. Precipitates were collected, filtered, dried, and recrystallized by ethanol. ${ }^{[8]}$

\section{General Method of Synthesis of}

\section{2,4-Thiazolidinedione (2)}

Equimolar quantities of chloroacetic acid (56.4 grams) and thiourea (45.6 grams) were mixed in $60 \mathrm{~mL}$ of $\mathrm{H}_{2} \mathrm{O}$ and stirred with a glass rod approximately for 15 minutes. White precipitates resulted from stirring were cooled and $60 \mathrm{~mL}$ concentrated $\mathrm{HCl}$ was added to it slowly from a dropping funnel. After the addition of concentrated $\mathrm{HCl}$ was completed, it was refluxed and stirred at a mild temperature of 100 to $110^{\circ} \mathrm{C}$ for 8 to 10 hours. The flask was cooled and washed the product with water, filtered, and collected as a cluster of white needle-like crystals. Recrystallization was afforded from ethyl alcohol. ${ }^{[10]} \mathrm{A}$ single patch was observed on the TLC plate identified the pureness of the product. n-Hexane:ethyl acetate (8:2) was used as a solvent system.
General Procedure for Synthesis of 5-Benzylidine

2,4-Thiazolidinedione (3)

Refluxation of 2,4-thiazolidinedione (2) (2.4 grams, $20 \mathrm{mmol}$ ), piperidine (1.4 grams, $16 \mathrm{mmol})$, benzaldehyde $(20 \mathrm{mmol})$, and EtOH $(150 \mathrm{~mL})$ was done for 16 to 24 hours. After refluxing, the reaction mixture was poured into $\mathrm{H}_{2} \mathrm{O}$ and acidified with acetic acid to give solids and recrystallized product with methanol. ${ }^{[11]}$

General Method of Synthesis of 4'-ChlorosulfonylBenzylidene 2,4Thiazolidinedione (4)

In a $100 \mathrm{~mL}$ RBF, 8 grams of benzylidine-2,4thiazolidinedione $(0.0388 \mathrm{M})$ was placed. 18.08 grams of chlorosulphonic acid $(0.155 \mathrm{M})$ was added dropwise at room temperature. The mixture was refluxed for 1-hour after the chlorosulphonic acid was added completely to water bath at $60^{\circ} \mathrm{C}$. The mixture was cooled completely and added over mashed ice. The product was filtered, dried, and purification is done by using ethanol. ${ }^{[12]}$

General Procedure for Synthesis of (E)-4- ((2,4Dioxothiazolidin-5-Ylidene)Methyl)-N-(5-(Phenyl)-1,3,4Thiadiazol-2-yl)Benzenesulfonamide (4a-4o)

For preparation of final compounds, equimolar quantities of intermediates (4) synthesized in the earlier step and thiadiazole derivatives (1) were taken in a flask, and refluxing was done for 4 hours. Completion of reaction is noticed by TLC using a solvent system of n-hexane:ethyl acetate (8:2). After the reaction is over, ice-cold water was added, and solid was precipitated, which was collected further and purified from alcohol. ${ }^{[13]}$

\section{Spectral Characterization of Titled Derivatives}

\section{Comp $4 a$}

Yield 76\%, MP-182 to $184^{\circ} \mathrm{C}$. FT-IR 3314 (NH), 3068 (C-H Ar), 2836 (CH Arylidene) $1671(\mathrm{C}=0) 1620(\mathrm{C}=\mathrm{C} \mathrm{Ar})$, $1367\left(\mathrm{SO}_{2}\right), 775(\mathrm{Cl}), 666(\mathrm{C}-\mathrm{S}) ;{ }^{1} \mathrm{H}-\mathrm{NMR} 6.95$ to $7.39(\mathrm{~m}, 7 \mathrm{H}$, ArH), 7.24 (s, 1H, CH), 4.01 (s, 1H, NH); ${ }^{13} \mathrm{C}-\mathrm{NMR} 155.04$, $134.00,132.83,132.11,127.60,126.47,125.85,124.70 . \mathrm{MS}$ ES+ (ToF): $m / z 511.92$

\section{Comp $4 b$}

Yield 81\%, MP-155 to $157^{\circ} \mathrm{C}$. FT-IR 3335 (NH), 3002 (C-H Ar), 2946 (CH Arylidene) 1670 (C=0)1588 (C=C Ar), $1393\left(\mathrm{SO}_{2}\right), 1333\left(\mathrm{NO}_{2}\right), 761(\mathrm{Cl}), 685(\mathrm{C}-\mathrm{S}) ;{ }^{1} \mathrm{H}-\mathrm{NMR}$ 7.07$7.62(\mathrm{~m}, 7 \mathrm{H}, \mathrm{ArH}), 7.19(\mathrm{~s}, 1 \mathrm{H}, \mathrm{CH}),{ }^{13} \mathrm{C}-\mathrm{NMR} 168.41,166.94$, $157.40,153.40,138.28,132.51,131.29,13.72,130.04$, 128.43, 113.05. MS ES+ (ToF): $m / z 522.95$

\section{Comp 4c}

Yield 59\%, MP-161 to $163^{\circ} \mathrm{C}$. FT-IR 3371 (NH), 3118 (C-H Ar), 2956 (CH Arylidene) $1678(\mathrm{C}=0), 1328\left(\mathrm{SO}_{2}\right), 721(\mathrm{Cl})$, 672(C-S); ${ }^{1} \mathrm{H}-\mathrm{NMR} 7.28$ to 8.08 (m, 7H, ArH), 7.53 (s, $1 \mathrm{H}$, $\mathrm{CH}), 3.97$ (s, $1 \mathrm{H}, \mathrm{NH}) ;{ }^{13} \mathrm{C}-\mathrm{NMR} 155.04,134.00,132.83$, $132.11,127.60,126.47,125.85,124.70 . \mathrm{MS}$ ES+ (ToF): $\mathrm{m} / \mathrm{z} 511.92$ 
Synthesis and Antidiabetic Evaluation of some Novel Nitrogen-containing Small Heterocyclic Derivatives

\section{Comp $4 d$}

Yield 77\%, MP-150 to $152^{\circ} \mathrm{C}$. FT-IR 3287(NH), 2963 (C-H Ar), 2835 (CH Arylidene) 1673 (C=0), 1590 (C=C Ar), $1394\left(\mathrm{SO}_{2}\right), 771(\mathrm{Cl}), 677(\mathrm{C}-\mathrm{S}) ;{ }^{1} \mathrm{H}-\mathrm{NMR} 7.03$ to $7.32(\mathrm{~m}$, $8 \mathrm{H}, \mathrm{ArH}), 7.22(\mathrm{~s}, 1 \mathrm{H}, \mathrm{CH}), 3.60(\mathrm{~s}, 1 \mathrm{H}, \mathrm{NH}) \cdot{ }^{13} \mathrm{C}-\mathrm{NMR} 168.41$, $166.94,157.40,153.40,138.28,132.51,131.29,13.72$, 130.04, 128.43, 113.05.MS ES+ (ToF): $m / z 477.96$

\section{Comp $4 e$}

Yield 63\%, MP-191 to $193^{\circ} \mathrm{C}$. FT-IR 3359 (NH), 3120 (C-H Ar), 2774 (CH Arylidene) 1630 (C=0), 1585 (C=C Ar), $1394\left(\mathrm{SO}_{2}\right), 1332\left(\mathrm{NO}_{2}\right), 727(\mathrm{Cl}), 669(\mathrm{C}-\mathrm{S}) ;{ }^{1} \mathrm{H}-\mathrm{NMR} 6.94$ $9.50(\mathrm{~m}, 6 \mathrm{H}, \mathrm{ArH}), 7.92(\mathrm{~s}, 1 \mathrm{H}, \mathrm{CH}), 3.78(\mathrm{~s}, 1 \mathrm{H}, \mathrm{NH}) ;{ }^{13} \mathrm{C}-\mathrm{NMR}$ 155.04, 134.00, 132.83, 132.11, 127.60,126.47, 125.85, 124.70.MS ES+ (ToF): $m / z 556.91$

\section{Comp $4 f$}

Yield 78\%, MP-222 to $224^{\circ} \mathrm{C}$. FT-IR 3319 (NH), 3060 (C-H Ar), 2811 (CH Arylidene) 1525 (C=C Ar), $1392\left(\mathrm{SO}_{2}\right), 1281$ $\left(-\mathrm{OCH}_{3}\right), 749(\mathrm{Cl}), 695(\mathrm{C}-\mathrm{S}) ;{ }^{1} \mathrm{H}-\mathrm{NMR} 7.13$ to $7.44(\mathrm{~m}, 6 \mathrm{H}$, $\mathrm{ArH}), 7.16$ (s, $1 \mathrm{H}, \mathrm{CH}), 3.38\left(\mathrm{~s}, 3 \mathrm{H}, \mathrm{OCH}_{3}\right) ;{ }^{13} \mathrm{C}-\mathrm{NMR} 155.42$, 133.86, 132.05, 129.83, 127.80, 126.53, 124.73, 40.64.MS $\mathrm{ES}+(\mathrm{ToF}): m / z 541.93$

\section{Comp $4 g$}

Yield 70\%, MP-174 to $176^{\circ} \mathrm{C}$. FT-IR 3310 (NH), 3077 (C-H Ar), 2852 (CH Arylidene) 1688 (C=0), 1602 (C=C Ar), $1349\left(\mathrm{SO}_{2}\right), 1281\left(-\mathrm{OCH}_{3}\right), 757(\mathrm{Cl}), 693(\mathrm{C}-\mathrm{S}) ;{ }^{1} \mathrm{H}-\mathrm{NMR}$ 7.02 to $7.88(\mathrm{~m}, 6 \mathrm{H}, \mathrm{ArH}), 7.16(\mathrm{~s}, 1 \mathrm{H}, \mathrm{CH}), 4.40(\mathrm{~s}, 1 \mathrm{H}, \mathrm{NH})$; 3.47 (s, 3H, $\mathrm{OCH}_{3}$ ). ${ }^{13} \mathrm{C}-\mathrm{NMR} 166.00,155.16,133.95,132.13$, 127.62, 126.48, 124.70, 40.74.MS ES+ (ToF): $m / z 541.93$

\section{Comp $4 h$}

Yield 63\%, MP-209 to $211^{\circ} \mathrm{C}$. FT-IR 3317 (NH), 3036 (C-H Ar), 2849 (CH Arylidene) 1673 (C=0), 1637 (C=C Ar), $1390\left(\mathrm{SO}_{2}\right), 758(\mathrm{Cl}), 648(\mathrm{C}-\mathrm{S}) ;{ }^{1} \mathrm{H}-\mathrm{NMR} 6.58$ to $7.96(\mathrm{~m}, 6 \mathrm{H}$, ArH), 7.26 (s, 1H, CH), 3.53 (s, 1H, NH); ${ }^{13} \mathrm{C}-\mathrm{NMR} 161.68$, $160.52,150.11,147.54,133.96,132.14,127.67,126.48$, 125.94, 124.68, 122.80, 112.54.MS ES+ (ToF): $m / z 547.88$

\section{Comp $4 i$}

Yield 60\%, MP-181 to $183^{\circ} \mathrm{C}$. FT-IR 3357 (NH), 1699 (C=0), 1628 (C=C Ar), $1294\left(\mathrm{NO}_{2}\right), 790$ (Cl), 695(C-S); ${ }^{1} \mathrm{H}-\mathrm{NMR}$ : 6.21 to 7.5 (m, 7H, ArH), $7.14(\mathrm{~s}, 1 \mathrm{H}, \mathrm{CH}),{ }^{13} \mathrm{CNMR}$ 158.72, 155.37, 135.20, 134.00, 132.79, 132.11, 130.97, 129.60, 127.64, 126.49, 124.65.MS ES+ (ToF): $m / z 556.91$

\section{Comp $4 j$}

Yield 57\%, MP-157 to $159^{\circ} \mathrm{C}$. FT-IR 3335 (NH), 3032 (C-H Ar), 2969 (CH Arylidene) 1691 (C=0), 1609 (C=C Ar), $1365\left(\mathrm{SO}_{2}\right)$, 783 (Cl), 623 (C-S); ${ }^{1} \mathrm{H}-\mathrm{NMR} 7.09$ to 7.71 (m, 6H, ArH), 7.35 (s, 1H, CH). ${ }^{13} \mathrm{C}-\mathrm{NMR} 155.04,134.00,132.83,132.11,127.60$, 126.47, 125.85, 124.70.MS ES+ (ToF): $m / z 547.88$

\section{Comp $4 k$}

Yield 83\%, MP-170 to $172^{\circ} \mathrm{C}$. FT-IR 3364 (NH), 3079 (C-H Ar), 2962 (CH Arylidene) 1639 (C=0), 1602 (C=C Ar),
$1353\left(\mathrm{SO}_{2}\right), 789(\mathrm{Cl}), 658(\mathrm{C}-\mathrm{S}) ;{ }^{1} \mathrm{H}-\mathrm{NMR} 7.46$ to 9.06 (m, 7H, ArH), 7.49 (s, 1H, CH), 4.08 (s, 1H, NH); ${ }^{13} \mathrm{C}-\mathrm{NMR} 160.84$, $160.51,152.08,149.42,127.13,125.05,112.88,110.96$, 110.30, 108.65.MS ES+ (ToF): $m / z 511.92$

\section{Comp 41}

Yield 74\%, MP-144 to $146^{\circ} \mathrm{C}$. FT-IR 3362 (NH), 2990 (C-H Ar), 2814 (CH Arylidene) 1688 (C=0), 1607 (C=C Ar), $1398\left(\mathrm{SO}_{2}\right), 1349\left(\mathrm{NO}_{2}\right), 1270\left(-\mathrm{OCH}_{3}\right), 651(\mathrm{C}-\mathrm{S}) ;{ }^{1} \mathrm{H}-\mathrm{NMR}$ 6.91 to $8.13(\mathrm{~m}, 7 \mathrm{H}, \mathrm{ArH}), 6.94(\mathrm{~s}, 1 \mathrm{H}, \mathrm{CH}), 3.37$ (s, 3H, $\left.-\mathrm{OCH}_{3}\right) .{ }^{13} \mathrm{C}-\mathrm{NMR} 165.27,162.70,143.12,135.18,125.32$, $128.20,126.21,121.54,119.75,87.43,77.01 . M S E S+(T o F):$ $m / z 519.00$

\section{Comp $4 m$}

Yield 68\%, MP-234 to $236^{\circ} \mathrm{C}$. FT-IR 3301 (NH), 2996 (C-H Ar), 2882 (CH Arylidene) 1681 (C=0), 1649 (C=C Ar), $1397\left(\mathrm{SO}_{2}\right), 1226\left(-\mathrm{OCH}_{3}\right), 668(\mathrm{C}-\mathrm{S}) ;{ }^{1} \mathrm{H}-\mathrm{NMR} 6.95$ to 7.57 (m, 7H, ArH), 7.25 (s, 1H, CH), 3.84 (s, 1H, NH), 3.59 (s, $\left.6 \mathrm{H},-\mathrm{OCH}_{3}\right) ;{ }^{13} \mathrm{C}-\mathrm{NMR} 169.13,167.27,160.70,143.12,135.18$, $128.32,127.20,126.21,120.54,119.75,77.43,77.01 . M S$ $\mathrm{ES}+(\mathrm{ToF}): m / z 504.02$

\section{Comp $4 n$}

Yield 74\%, MP-188 to $190^{\circ} \mathrm{C}$. FT-IR 3412 (NH), 2960 (C-H Ar), 2830 (CH Arylidene) 1592 (C=C Ar), $1387\left(\mathrm{SO}_{2}\right)$, $1266\left(-\mathrm{OCH}_{3}\right), 770(\mathrm{Cl}), 637(\mathrm{C}-\mathrm{S}) ;{ }^{1} \mathrm{H}-\mathrm{NMR} 7.37$ to $8.63(\mathrm{~m}$, 7H, ArH), 7.53 (s, 1H, CH), 4.10 (s, 1H, NH) 3.72 (s, 3H, $\left.-\mathrm{OCH}_{3}\right) ;{ }^{13} \mathrm{C}-\mathrm{NMR} 169.13,167.27,160.70,143.12,135.18$, $128.32,127.20,126.21,120.54,119.75,77.01 M S E S+(T o F):$ $m / z 507.97$

\section{Comp 40}

Yield 65\%, MP-155 to $157^{\circ} \mathrm{C}$. FT-IR 3361 (NH), 3012 (C-H Ar), 2988 (CH Arylidene) 1692 (C=0), 1649 (C=C Ar), $1391\left(\mathrm{SO}_{2}\right), 1260\left(-\mathrm{OCH}_{3}\right), 666(\mathrm{C}-\mathrm{S}) ; 6.47$ to $7.39(\mathrm{~m}, 8 \mathrm{H}$, ArH), 7.21 (s, 1H, CH), $3.82(\mathrm{~s}, 1 \mathrm{H}, \mathrm{NH}), 3.72\left(\mathrm{~s}, 3 \mathrm{H},-\mathrm{OCH}_{3}\right)$. ${ }^{13} \mathrm{C}-\mathrm{NMR}$ 165.27, 162.70, 143.12, 135.18, 125.32, 128.20, 126.21, 121.54, 119.75, 87.43, 77.01.MS ES+ (ToF): m/ $z 474.01$

\section{Anti-Diabetic Evaluation}

\section{Alloxan-induced Model}

The animals were made to adapt and fasted overnight. On the day of starting, all the animals receive a dose of $120 \mathrm{mg} / \mathrm{kg}$ i.p. of alloxan monohydrate prepared in normal saline. This group serves as alloxan control for comparison. To beat the early hypoglycemic phase a solution of $5 \%$ dextrose was dispensed for a day. The standard group was given an injection of glibenclamide in a dose of $5 \mathrm{mg} / \mathrm{kg}$ of the body weight. The test compounds ( $50 \mathrm{mg} / \mathrm{kg}$ ) were dispensed orally by making a solution with CMC $(0.25 \%)$. The level of blood glucose was monitored by collecting the blood from tail vein on the strip of glucometer, and readings were noted on 0 -day, 3rd day, and 7th day of the model. ${ }^{[14]}$ 


\section{Oral Glucose Tolerance Test (OGTT)}

The OGTT was carried out subsequently after 15 days of diet treatment. After 8 hours of fasting, dextrose solution ( $2 \mathrm{~g} / \mathrm{kg}$ body weight) was administrated intraperitoneally, and blood glucose levels collected from tail vein were checked at $0,30,60$, and 120 minutes afterward glucose injection using a glucometer (Accu-Chek). ${ }^{[15]}$

\section{Molecular Modelling}

\section{Docking}

Molecular docking experiments were carried out on seven enzymes by using the molecular Design Suite (V-Life MDS 3.0 software package, version 3.0, from VLife Sciences, Pune, India), on a Windows 7, Windows Server 2008 R2 (operating system version 6.1), Genuine Intel Computer ID: 783232402132454023. The crystal structures of peroxisome proliferator-activated receptorgamma (PPARG) (PDB Code-2XKW, resolution: $\left.3.1 \mathrm{~A}^{\circ}\right)^{[16]}$ were digitized from Research Collaboratory for Structural Bioinformatics (RCSB) protein data bank (PDB). The modification of the basic PDB structure of the protein was carried out by managing the imperfect and missing amino acid residues. The ligand previously embedded within the structure of the protein was amended. To the crystal structure of the protein side-chain, hydrogens were added and then provided with hydrogen atoms in the side-chain, and finally, they were upraised up to the root mean squared (RMS) gradient 1 . The receptor was then optimized and converted into as mol file and saved in a folder for docking purposes. The ligands with low energy conformation were selected and docked with standard precision (SP) docking mode into the grid generated from protein structure.

\section{RESULTS AND DiscusSion}

Five or six-membered heterocyclic aromatic compounds have been under exploration for a long time because of their wide range of biological activities. In small-molecule heterocyclic compounds, thiadiazole and thiazolidinedione are known scaffolds for potential drugs. Plasma glucose and insulin levels are reduced by thiazolidinediones (TZDs), and some of the abnormalities of lipid metabolism also get improved. Moreover, several heterocyclic moieties, such as, benzoxazinone, benzoxazole, benzofuran, pyrimidinone, etc., have been clubbed with thiazolidine-2,4-dione and were found to show a good to a significant profile of activities. ${ }^{[9]}$ Therefore, a conscious effort is made in the chemistry part of the present work to cull out selective modifications of the thiadiazole and dione skeletons.

\section{Chemistry}

Series of derivatives (4a-4o) was designed and synthesized, according to Synthetic scheme mentioned in Fig. 1. A reaction of benzoic acid with thiosemicarbazide was done in the presence of phosphorus oxychloride to yield the desired amino thiadiazoles. In another step, portions of chloroacetic acid and thiourea were mixed together, a white precipitate formed after stirring for 15 minutes, to which was added dropwise in small parts of concentrated hydrochloric acid (60 $\mathrm{mL}$ ) from a dropping funnel and refluxed for 8 to 10 hours to yield the 2,4-thiazolidinedione, proceeding which aromatic aldehyde was then attached to the thiazolidinedione system in the presence of piperidine. After that, chlorosulphonic acid was reacted with benzylidene derivatives to give up the chlorosulfonylthiazolidinedione. At the last step, both the intermediates were joined together to form title compounds (4a-4o). Molecular weights of all the synthesised compounds were depicted in Table $1 .{ }^{1} \mathrm{H}-\mathrm{NMR}$ reveals the existence of singlet for $-\mathrm{NH}$ group at $\delta 3.14$ along with the absence of singlet for two protons of $-\mathrm{NH}_{2}$ group of thiadiazole at $\delta 4.52$ to 7.01 , which proved the product formation. The

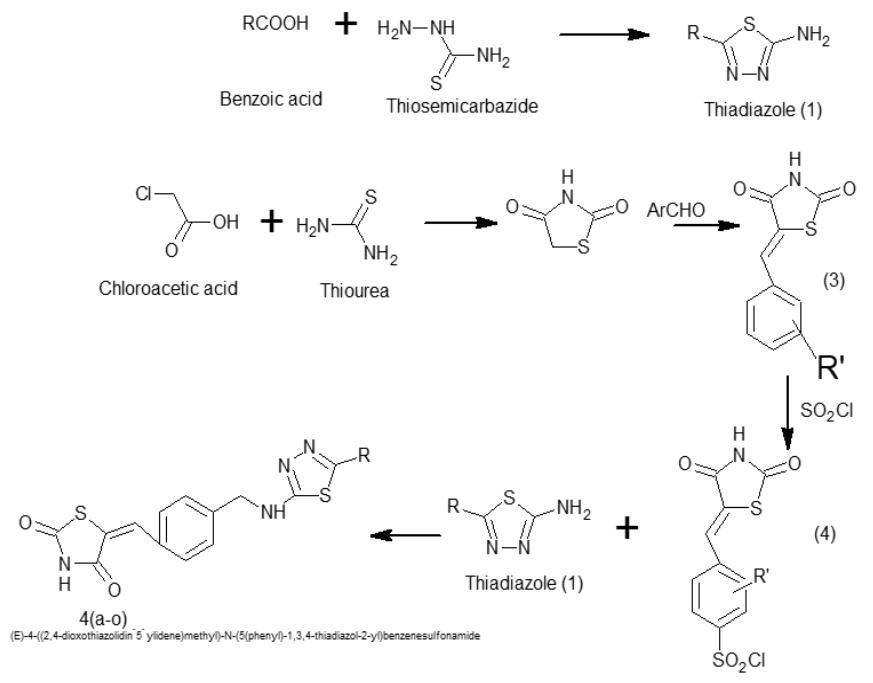

Fig. 1: Synthetic scheme for title derivatives $(4 a-4 o)$

Table 1: Derivatives 4a-4o with molecular weights

\begin{tabular}{llll}
\hline S. No. & $R$ & $R^{\prime}$ & Mol. Wt. \\
\hline $4 \mathrm{a}$ & p-chloro phenyl & $2-\mathrm{Cl}$ & 513.4 \\
$4 \mathrm{~b}$ & -do- & $2-\mathrm{NO}_{2}$ & 523.95 \\
$4 \mathrm{c}$ & -do- & $3-\mathrm{Cl}$ & 513.4 \\
$4 \mathrm{~d}$ & -do- & - & 478.95 \\
$4 \mathrm{e}$ & 2,4 -dichloro phenyl & $3-\mathrm{NO}_{2}$ & 558.39 \\
$4 \mathrm{f}$ & -do- & $3-\mathrm{OCH}_{3}$ & 543.42 \\
$4 \mathrm{~g}$ & -do- & $2-\mathrm{OCH}_{3}$ & 543.42 \\
$4 \mathrm{~h}$ & -do- & $2-\mathrm{Cl}$ & 547.84 \\
$4 \mathrm{i}$ & -do- & $2-\mathrm{NO}_{2}$ & 558.39 \\
$4 \mathrm{j}$ & -do- & $3-\mathrm{Cl}$ & 547.84 \\
$4 \mathrm{k}$ & -do- & - & 513.4 \\
$4 \mathrm{l}$ & -do- & $3-\mathrm{NO}_{2}$ & 519.33 \\
$4 \mathrm{~m}$ & 2 -methoxy phenyl & $3-\mathrm{OCH}_{3}$ & 504.56 \\
$4 \mathrm{n}$ & -do- & $3-\mathrm{Cl}$ & 508.98 \\
40 & -do- & - & 474.73 \\
\hline
\end{tabular}


appearance of one proton singlet in the range $\delta 2$ to 5 in NMR spectra confirmed the fusion of thiadiazole moiety with thiazolidinediones.

\section{Biological Activity}

Synthesized compounds were screened for their efficiency against diabetes is calculated by alloxan-induced model ${ }^{[14]}$ and oral glucose tolerance test. ${ }^{[15]}$ In the case of the alloxaninduced model, the level of blood glucose was mentored at 0 -day, 3rd day, and 7th day. In the case of oral glucose tolerance test, after 8 hours of fasting, blood glucose levels were resoluted at intervals of $0,30,60$, and 120 minutes after glucose solution administration, using a glucometer. The results for the models were represented in Tables 2 and 3 .

From the results of the alloxan model, compound $4 \mathrm{k}$ with o,p-dichloro group was found to be the most dynamic one with significant reductions in blood glucose level (141.22 \pm 10.35 ) as compared to control. Similarly, another compound 41 with meta nitro group gave good results as compared to standard drug. In the case of oral glucose tolerance test, after 8 hours of fasting, glucose solution ( $2 \mathrm{~g} / \mathrm{kg}$ body weight) was administrated intraperitoneally, and tail vein blood glucose levels were checked at $0,30,60$, and 120 minutes after glucose injection, using a glucometer. Results described that compounds $4 \mathrm{j}$ with ortho, para-dichloro groups, respectively, showed a significant reduction in blood glucose $(82.9 \pm 1.79)$ and $(84.05 \pm 1.45)$ compared to the standard drug glibenclamide.

\section{Docking}

A preferred geometry of interaction of ligand-receptor complexes with minimum interaction energy grounded on diverse scoring functions, such as, electrostatic forces, the sum of steric and electrostatic forces, and the dock score is termed as molecular docking. ${ }^{[17]}$ The synthesized compounds of both the series interacted with the active site of proteins using VLife MDS 3.0 software package to understand the binding interactions. From the complete analysis, it was concluded that almost all compounds had shown interactions with proteins with considerable scores. The docking results illustrated that the thiadiazole center of these compounds was gripped in the active pocket by forming the hydrophobic and hydrogen bonding interaction with amino acid residues. Receptor PPARG (PDB code-2KXWY, resolution: $3.1 \mathrm{~A}^{\circ}$ ) was digitized from the RCSB protein data bank. After minimizing the energy, all generated conformers were placed in the GRIP docking wizard selected from the Biopredicta module. The conformer with the best dock result is kept safe in the output folder. The conformer with the best orientation in the receptor's binding pocket having a minimum dock score with more negative value on the scoring function indicated better docking. The interaction energy of the ligands and their interactions has presented appreciable results. The optimized complexes were then analyzed for various interactions of the molecule with protein and hydrogen bonding, and many other types of interactions, like van der Waals interaction and hydrophobic bonding, were revealed.

Table 2: Anti-diabetic activity of derivatives (4a-4o) by alloxan-induced model

\begin{tabular}{|c|c|c|c|c|}
\hline \multirow[b]{2}{*}{ S. No. } & \multirow[b]{2}{*}{ Dose $(\mathrm{mg} / \mathrm{kg})$} & \multicolumn{3}{|c|}{ Glucose concentration $(\mathrm{mg} / \mathrm{dL})$} \\
\hline & & 0-day & 3rd day & 7th day \\
\hline Normal control & - & $81.9 \pm 0.71$ & $79.95 \pm 0.58$ & $81.25 \pm 0.45$ \\
\hline Alloxan control & 120 & $224.28 \pm 4.22$ & $270.95 \pm 9.58$ & $292.3 \pm 8.92$ \\
\hline Glibenclamide & 5 & $216.3 \pm 1.78$ & $130.52 \pm 16.23^{* * *}$ & $96.4 \pm 15.22^{* * *}$ \\
\hline $4 a$ & 50 & $226.28 \pm 1.69$ & $244.62 \pm 1.77$ & $154.72 \pm 1.89^{*}$ \\
\hline $4 b$ & 50 & $231.55 \pm 1.09$ & $235.2 \pm 2.57$ & $166.45 \pm 9.65^{*}$ \\
\hline $4 c$ & 50 & $224.78 \pm 4.79$ & $227.17 \pm 1.92^{*}$ & $168.02 \pm 8.65^{*}$ \\
\hline $4 d$ & 50 & $224.43 \pm 2.36$ & $232.4 \pm 2.23^{*}$ & $154.7 \pm 1.56^{*}$ \\
\hline $4 \mathrm{e}$ & 50 & $234.28 \pm 1.17$ & $223.15 \pm 0.87$ & $163.8 \pm 9.35$ \\
\hline $4 \mathrm{f}$ & 50 & $235.38 \pm 1.38$ & $233.32 \pm 4.1$ & $154 \pm 11.44$ \\
\hline $4 \mathrm{~g}$ & 50 & $230.48 \pm 6.2$ & $224.2 \pm 2.05$ & $155.1 \pm 10.75$ \\
\hline $4 \mathrm{~h}$ & 50 & $237.65 \pm 2.73$ & $230.82 \pm 2.78$ & $154.15 \pm 11.46$ \\
\hline $4 \mathrm{i}$ & 50 & $237.08 \pm 2.7$ & $224.27 \pm 1.6$ & $166.45 \pm 9.42$ \\
\hline $4 j$ & 50 & $238.9 \pm 2.24$ & $233.7 \pm 2.3$ & $165.1 \pm 10.18$ \\
\hline $4 \mathrm{k}$ & 50 & $224.78 \pm 4.79$ & $223.15 \pm 3.03^{* *}$ & $141.22 \pm 10.35^{* *}$ \\
\hline 41 & 50 & $223.83 \pm 2.64$ & $210.2 \pm 6.31^{* *}$ & $166.15 \pm 7.64^{* *}$ \\
\hline $4 \mathrm{~m}$ & 50 & $237.35 \pm 6.32$ & $210.2 \pm 1.98^{*}$ & $155.1 \pm 10.67^{*}$ \\
\hline $4 n$ & 50 & $226.33 \pm 3.74$ & $209.3 \pm 0.71^{*}$ & $153.22 \pm 10.52^{*}$ \\
\hline 40 & 50 & $227.45 \pm 1.08$ & $224.45 \pm 0.65$ & $153.22 \pm 10.78$ \\
\hline
\end{tabular}

Each value was expressed in a Mean \pm SEM; obtained results were analysed by statistically using one-way, ANOVA followed by Dunnett's' $t$ ' test $(n=6)$; Significant $\mathrm{p}$ values are ${ }^{* *}$ regarded to be $\mathrm{p}<0.05$ and $^{* * *} \mathrm{p}<0.0001$. 
Gagandeep Kaur et al.

Table 3: Anti-diabetic activity of derivatives (4a-4o) by oral glucose tolerance test

\begin{tabular}{|c|c|c|c|c|c|}
\hline \multirow[b]{2}{*}{ Treatment } & \multirow[b]{2}{*}{ Dose $(\mathrm{mg} / \mathrm{kg})$} & \multicolumn{4}{|c|}{ Glucose concentration $(\mathrm{mg} / \mathrm{dL})$} \\
\hline & & 0 mins & 30 mins & 60 mins & 120 mins \\
\hline Normal control & $0.9 \%$ saline & $72.82 \pm 2.97$ & $77.52 \pm 1.86$ & $72.62 \pm 1.6$ & $75.45 \pm 1.25$ \\
\hline $10 \%$ glucose & 2 & $80.47 \pm 2.08$ & $143.57 \pm 2.05$ & $156.9 \pm 1.17$ & $137.05 \pm 1.62$ \\
\hline Glibenclamide & 5 & $78.55 \pm 1.53^{* *}$ & $67.27 \pm 2.27^{* * *}$ & $71.7 \pm 1.49^{* * *}$ & $68.8 \pm 1.18^{* * *}$ \\
\hline $4 a$ & 50 & $89.52 \pm 0.72$ & $154.3 \pm 1.26$ & $136.42 \pm 1.25$ & $104.42 \pm 1.46$ \\
\hline $4 \mathrm{~b}$ & 50 & $88.3 \pm 0.51$ & $141.42 \pm 1.04$ & $115.07 \pm 1.56^{*}$ & $94.37 \pm 1.23^{*}$ \\
\hline $4 c$ & 50 & $88.47 \pm 0.78$ & $134.27 \pm 1.71^{*}$ & $124.8 \pm 1.03^{*}$ & $96.47 \pm 1.99^{*}$ \\
\hline $4 d$ & 50 & $87.3 \pm 0.75$ & $141.67 \pm 1.48$ & $107.95 \pm 1.9^{*}$ & $105.17 \pm 1.18$ \\
\hline $4 \mathrm{e}$ & 50 & $89.42 \pm 1.26$ & $137 \pm 1.01^{*}$ & $127.75 \pm 1.23$ & $124.2 \pm 1.68$ \\
\hline $4 \mathrm{f}$ & 50 & $87 \pm 1.11$ & $139.1 \pm 1.93^{*}$ & $125.55 \pm 1.71$ & $111.1 \pm 1.79$ \\
\hline $4 g$ & 50 & $87.27 \pm 0.67$ & $143.92 \pm 1.71$ & $126.22 \pm 1.14$ & $108.7 \pm 1.43$ \\
\hline $4 \mathrm{~h}$ & 50 & $88 \pm 1.37$ & $134.55 \pm 1.83^{*}$ & $106.52 \pm 1.81^{*}$ & $105.77 \pm 1.35$ \\
\hline $4 \mathrm{i}$ & 50 & $91.3 \pm 0.5$ & $135.35 \pm 1.23^{*}$ & $106.32 \pm 1.46^{*}$ & $95.45 \pm 1.42^{*}$ \\
\hline $4 j$ & 50 & $88.17 \pm 1.21$ & $135.5 \pm 1.93^{*}$ & $114.57 \pm 1.86^{*}$ & $84.05 \pm 1.45^{*}$ \\
\hline $4 \mathrm{k}$ & 50 & $89.47 \pm 0.06$ & $143.57 \pm 1.24$ & $107.95 \pm 1.78^{*}$ & $95.5 \pm 1.43^{*}$ \\
\hline 41 & 50 & $88.35 \pm 0.64$ & $134.72 \pm 1.77^{*}$ & $114.1 \pm 1.74^{*}$ & $103.57 \pm 1.67$ \\
\hline $4 \mathrm{~m}$ & 50 & $87.87 \pm 0.81$ & $134.27 \pm 1.88^{*}$ & $106.62 \pm 1.84^{*}$ & $89.07 \pm 1.91^{*}$ \\
\hline $4 n$ & 50 & $87.72 \pm 0.49$ & $145.75 \pm 1.99$ & $125.55 \pm 1.27$ & $95.02 \pm 1.06^{*}$ \\
\hline 40 & 50 & $91.50 \pm 0.51$ & $139.1 \pm 1.44^{*}$ & $113.77 \pm 1.45^{*}$ & $94.56 \pm 1.45^{*}$ \\
\hline
\end{tabular}

Each value was expressed in a Mean \pm SEM; obtained results were analysed by statistically using one-way ANOVA, followed by Dunnett's' $\mathrm{t}^{\prime}$ test $(n=6)$; Significant $\mathrm{p}$ values are ${ }^{* *}$ regarded to be $\mathrm{p}<0.05$ and $^{* * *} \mathrm{p}<0.0001$.

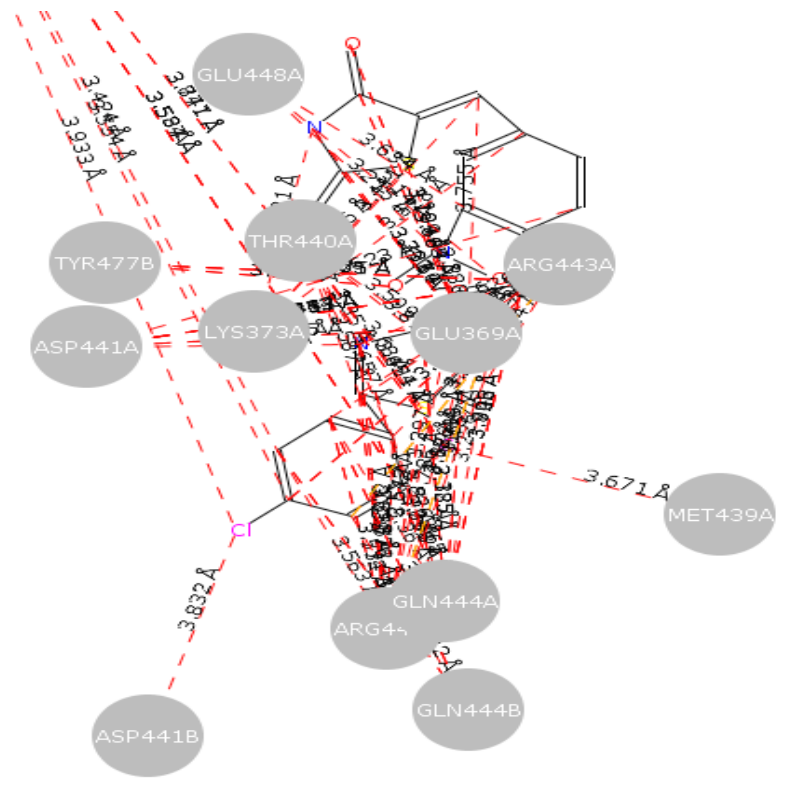

Fig. 2: Image of ligand in cavity with minimum score are represented here with hydrogen bonding interaction, hydrophobic interactions, and van der Waals interactions shown with dotted lines in blue, green, and red colors, respectively

The minimum score has been obtained for ligand 40 with the dock score of $-82.907601 \mathrm{kcal} / \mathrm{mol}$ with different interactions between amino acid PR0206A, GLU207A, GLU448A, ASP210A, GLN444B, and TYR447B, as shown in Fig. 2. Here, it is concluded that the thiazolidinedione ring's nitrogen atoms, the carbonyl group of thiazolidinedione, are involved in hydrogen bonding and van der Waals interactions. All compounds provided satisfactory dock scores ranging from -82.907601 to $-30.114406 \mathrm{kcal} / \mathrm{mol}$.

\section{Structure-Activity Relationship (SAR)}

From all the above data obtained from biological and computational studies of novel synthesized compounds, SAR is derived, and it shows that specifically, substituted thiazolidinedione-thiadiazoles are more potent than non-substituted derivatives. The occurrence of the electron-withdrawing substituents, like o, $\mathrm{p}-\mathrm{NO}_{2}$, and $\mathrm{Cl}$ groups on phenyl ring substituted on thiadiazole and thiazolidinedione, may be responsible for the improvement in the in vivo biological potential. It is observed that the dock score predicted by the software is in good correlation with the experimental values. It culminates from the overall comparison of computational and biological activity that substituents have variable effects on the observed pharmacological activities. It is concluded from the SAR that derivatives $4 \mathrm{c}$ and $4 \mathrm{k}$ possessing electronwithdrawing groups were found to be highly active for the in vivo anti-diabetic activity.

\section{Conclusion}

From all the data obtained from the computational and biological evaluation of the novel synthesized compounds, the structure-activity relationship was derived, and it shows that for most of the compounds, the occurrence of an electron-withdrawing group on arylidene ring of 
a thiazolidinedione and heterocyclic ring system, i.e., thiadiazole nucleus potentially increases the biological profile of the series. It is observed that the dock score predicted by the software is in good correlation with the experimental values. It culminates from the overall comparison of all the biological activities that substituents have variable effects on the observed pharmacological actions. The substituents, like chloro and nitro, added on the core structure were more potent inhibitors than methyl phenyl derivatives. Therefore, it is believed that the compounds from the present series can assist in the designing and development of new pharmacological agents.

\section{REFERENCES}

1. Carocho M, Ferreira ICFR. A review on antioxidants, prooxidants and related controversy: Natural and synthetic compounds, screening and analysis methodologies and future perspectives. Food Chem Toxicol. 2013;51:15-25.

2. Rani V, Deep G, Singh RK, Palle K, Yadav UCS. Oxidative stress and metabolic disorders: Pathogenesis and therapeutic strategies. Life Sci. 2016;148(1):183-193.

3. Resende MF, Lino CI, Fagundes DM, Rettore JV, Oliveira RB, Labanca RA. Assessment of anti-diabetic activity of a novel hydrazinethiazole derivative: in vitro and in vivo method. Braz. J. Pharm. Sci. 2019;55.

4. Avalakki AS, Jadhav SB, Bandawane DD, Bhalekar PA. Synthesis and anti-diabetic evaluation of some novel compounds. Int. J Chem. 2019;58B:849-854.

5. Nagappa AN, Thakurdesai PA, Venkat Rao N, Singh J. Antidiabetic activity of Terminalia catappa Linn. fruits. J. of Ethnopharmacol. 2003;88:45-50.
6. Serrano JJ. Toxico-pharmacologie experimentale des plantes medicinales. Actes du 1er Colloque Europeen d'Ethnopharmacologie. Office de la Recherche Scientifique et Techniques d'Outre Mer (ORSTOM). 1990;210-218.

7. WHO Expert Committee on Diabetes mellitus, 1980. second Report, Technical Report series 646. World Health Organisation, Geneva.

8. ShahnazM,PatelRB.Synthesis, characterisation of 2,4-thiazolidinedione derivatives and evaluation of their antioxidant derivatives. Journal of Drug Delivery and Therapeutics. 2013;3(6):96-101.

9. Imran M, Ilyas B, Deepanjali, Khan SM. Recent thiazolidinediones as antidiabetics. J Scientific and Industrial Res. 2007;66:99-109.

10. Hasmin MH, Gajjar AK, Savjani JK, Masilnayat A. Synthesis and anticonvulsant activity of novel 2,5-disubstituted-1,3,4-thiadiazole derivatives. Int J Pharm Tech Res. 2011;3(4):2017-2024.

11. Bruno G, Costantino L, Curinga C, Maccari R, Monforte F, Nicolo F, et al. Synthesis and aldose reductase inhibitory activity of 5-Arylidene-2,4-thiazolidinediones. Bioorg Med Chem. 2002;10:1077-1084.

12. Barbosa ML, Ramos TJ, Arantes AC, Martins MA, Silva PM, Barriero EJ, et al. Synthesis and pharmacological evaluation of novel phenyl sulfonamide derivatives designed as modulators of pulmonary inflammatory response. Molecules. 2012;17:14651-14672.

13. Potey LC, Kosalge SB, Hadke MK. Synthesis and antimicrobial activity of quinoxaline sulfonamide. Int J Adv Res Tech. 2013;2(12):126-134.

14. Pattan SR, Kittur BS, Sastry BS, Jadav SG, Thakur DK, Madamwar $\mathrm{SA}$, et al. Synthesis and evaluation of some novel 1,3,4-thiadiazoles for anti-diabetic activity. Indian J Chem. 2011;50B:615-618.

15. Anitha M, Sakthidevi G, Muthukumarasamy S, Mohan VR. Effect of Cynoglossum zeylanicum (Vahl ex Hornem) Thunb. ex Lehm. on oral glucose tolerance in rats. J App Pharma Sci. 2012;2(11):75-78.

16. Einstein M, Akiyama TE, Castriota GA, Wang CF, McKeever B, Mosley $\mathrm{RT}$, et al. The differential interactions of peroxisome proliferatoractivated receptor-gamma ligands with Tyr473 is a physical basis for their unique biological activities. Mol Pharmacol. 2008;73:62-74.

17. Bachwani M, Kumar R. Molecular Docking. IJRAP. 2011;2(6):17461751.

HOW TO CITE THIS ARTICLE: Kaur G, Rani I. Synthesis and antidiabetic evaluation of some novel nitrogen-containing small heterocyclic derivatives. Int. J. Pharm. Sci. Drug Res. 2020;12(5):473-479. DOI: 10.25004/IJPSDR.2020.120507 